\title{
Experiencing Science in a 21st Century Middle School Classroom
}

\author{
Jose Paulo C. dela Cruz ${ }^{\text {a,1 }}$
}

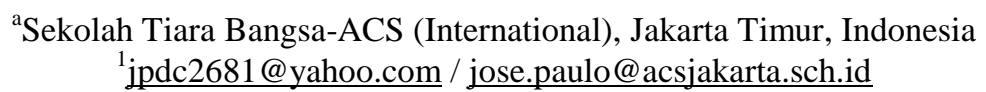

\begin{abstract}
The reason science is taught in schools is not only to inspire students to choose careers in science and technology but also to equip them with practical knowledge of how things work, build their science literacy to enable informed participation in science-related debates and issues, and develop their skills in scientific thinking and their knowledge of science as part of their intellectual enculturation. This paper presents Science Investigatory Project as a learning activity that is attuned with $21^{\text {st }}$ Century Education. Students were given opportunities to be engaged in exploring and solving socially relevant issues. They had hands-on experience on how scientific method works by designing their own fair tests, performing experiments showing cause-and-effect relationships, presenting and analyzing results through trends in graphs and communicate their results through a school-wide science fair. This learning activity engages students to be creative innovators by refining their method of investigating a problem; information literate by accessing reliable information through literature reviews; problem solvers by conducting experiments to verify their hypothesis; collaborators by working with partners and experts; communicators by writing a scientific paper, making display boards and orally present their findings; and, responsible citizens by coming up with a scientifically-verified solution to a problem.
\end{abstract}

Index Terms $-21^{\text {st }}$ century learning, science investigatory project, learning by inquiry.

\section{Introduction}

A holistic view of $21^{\text {st }}$ century teaching and learning focuses on the discrete combination of 21st century student outcomes (a blending of specific skills, content knowledge, expertise and literacies) with innovative support systems to help students master the multi-dimensional abilities required of them in the $21^{\text {st }}$ century and beyond [1].

The purpose of science education today should be aligned to produce a support system that produces $21^{\text {st }}$ century outcomes for today's students [2]. Science education should focus on the development of scientific literacy to enable understanding of the Nature of Science and its relationship to society, rather than a focus that is heavily weighted in content knowledge. This new approach should enable students to engage in thinking creatively, critically and constructively around complex real world problems $[3,4]$.

Learning sciences should develop students as inquirers, scientifically literate, caring and responsible individuals who will think critically and creatively when solving problems and making decisions about aspects affecting themselves, others and their social and natural environments - it is more than simply learning technical scientific terminology. As student learns science they should become competent and confident in accessing, using and communicating scientific information. Students are expected to use scientific language correctly and select appropriate communication formats for oral and written communication. They are also expected to demonstrate critical-thinking skills to analyze and evaluate information in order to make informed judgments in a variety of contexts [3,5].

This $21^{\text {st }}$ century purpose of science must be relevant to the interests of students, providing them with opportunities to explore the connections between science and everyday life. Students are encouraged to be interested in and engaged with the role of science in the world. Through the investigation of real examples of the application of science, students gain insight into the tensions and dependencies between science and societal, environmental and ethical factors [3].

This simply puts Inquiry as the heart of learning sciences and aims to support students' understanding of sciences by providing them with opportunities to independently investigate relevant issues through both research and experimentation.

The use of open, student-led investigations alongside scaffolded teaching of research skills and the integration of science process skills allows students at all levels to learn what it means to do science, solve problems and develop thinking skills [3]. Notably, these foundations are important for students who are going to continue in science, as well as for those who will not continue beyond secondary school [4].

The cognitive ability of creating meaning and structure from new information and experience are referred as science process skills. These skills are an important and necessary means by which the learner engages with the world and gains intellectual control of it through the formation of concepts and development of scientific thinking [5].

Science - A Process Approach (SAPA), defined science process skills as a set of broadly transferable abilities, appropriate to many science disciplines and reflective of the behavior of scientists. SAPA grouped process skills into two types basic and integrated. The basic (simpler) process skills provide a foundation for learning the integrated (more complex) skills.

The Basic Science Process Skills are:

Observing. The use of the senses to gather information about an object or event.

Inferring. The making an "educated guess" about an object or event based on previously gathered data or information.

Measuring. The use of both standard and nonstandard measures or estimates to describe the dimensions of an object or event. 
Communicating. The use of words or graphic symbols to describe an action, object or event.

Classifying. The grouping or ordering objects or events into categories based on properties or criteria.

Predicting. Stating the outcome of a future event based on a pattern of evidence.

The different Integrated Science Process Skills are:

Controlling variables. Being able to identify variables that can affect an experimental outcome, keeping most constant while manipulating only the independent variable.

Defining operationally. Stating how to measure a variable in an experiment.

Formulating hypotheses. Stating the expected outcome of an experiment.

Interpreting data. Organizing data and drawing conclusions from it.

Experimenting. Being able to conduct an experiment, including asking an appropriate question, stating a hypothesis, identifying and controlling variables, operationally defining those variables, designing a "fair" experiment, conducting the experiment, and interpreting the results of the experiment.

Formulating models. Creating a mental or physical model of a process or event.

Science process skills can be learned if taught in a formally in the classroom with the use of proven teaching methods. Furthermore, these skills can be retained for future use if lessons are based on science investigations and practiced over a long period of time.

A science investigation emphasizes the use of the scientific method in performing an investigation by experimentation (inquiry-based learning) to develop critical thinking and science process skills of the student. This scientific method allows scientists to collect and analyze data in a strategic and unified manner and this is the same method that students use to design and execute their project they use the same steps professional researchers use to gather new information. The different science process skills can be integrated in the conduct of science investigations [6]. Thus, the science investigations are giving students an opportunity to undergo the process of conducting an investigation using the scientific method making them gain a considerable understanding of the nature of obtaining solutions to problems or answers to questions in a systematic and scientific way.

This paper presents two approaches of doing science investigations in a middle school classroom - student-led investigation and structured-guided investigations. The effect of these approaches to students' integrated science process skills was investigated.

\section{Methodology}

\section{A. Subjects}

Two different subject groups were used in this study: student-led science investigatory project class and structured-guided experimental science class. The studentled science investigatory project class consisted of 55 grade 8 students who are enrolled in a middle science program with inquiry at the core of its framework. This class meets 5 periods in a week, during the second semester of the school year; two periods per week were used by students to independently and collaboratively investigate issues of their choice through research, observation and experimentation. At the end of the semester, the students were required to submit a full science investigatory report and make a display of the results of their investigations. This science curriculum enables the students to explore the connections between science and everyday life. The structured-guided experimental science class consisted of 21 students who were exposed to various science investigations chosen by the teacher. The class meets 7 periods in week. This class followed an 8-week researcher-developed curriculum. This experimental science module emphasizes the use of the scientific method in performing an investigation by experimentation (inquiry-based learning) to develop critical thinking and science process skills of the student. The students are given the opportunity to design and execute varied experiments in a strategic and unified manner. As students go through their investigations they are expected to master different Science Process Skills such as Identifying and Controlling Variables, Stating Hypotheses, Operational Definitions, Graphing and Interpreting Data, and Experimental Design. Students were required to submit a comprehensive written report for each science investigation they performed.

\section{B. Integrated Science Process Skills Test}

This study utilized a research-validated paper-andpencil test for assessing integrated science process skills developed by Kazeni (2005). The science process skills tested by the instrument are: identifying and controlling variables, stating hypotheses, experimental design, graphing and interpreting data and operational definitions. The test is consist of 30 multiple choice items that are content independent; and gender, race, school type and location neutral. For this study, some proper nouns were changed to a more locally family names to make the test more culturally valid.

\section{Test Administration and Analysis}

The integrated science process test was administered to student-led science investigatory project class at the end of the semester. The structured-guided experimental science class took the test after they finish the 8-week module. The mean of students' performance for each skill and their mean coverall performance were compared using t-Test for samples of equal variances. Students' proficiency levels were also interpreted as follows:

$$
\begin{aligned}
\leq 50 \% & \text { beginner, } \\
51-60 \% & \text { developing proficiency, } \\
61-75 \% & \text { proficient, and } \\
\geq 76 \% & \text { advanced proficiency. }
\end{aligned}
$$

\section{Results and Discussion}

\section{A. Integrated Science Process Skills}

Figure 1 shows the performance of the students in each skill tested through the Integrated Science Process Skills 
Test. Science process skills are defined as a set of broadly transferrable abilities that reflect the behavior of scientists. Students show a proficient level of identifying variables (71\%), graphing and interpreting data (69\%) and experimental design $(61 \%)$. Students displayed a beginning proficiency in their skills of stating hypotheses (48\%) and operationally defining variables in an investigation.

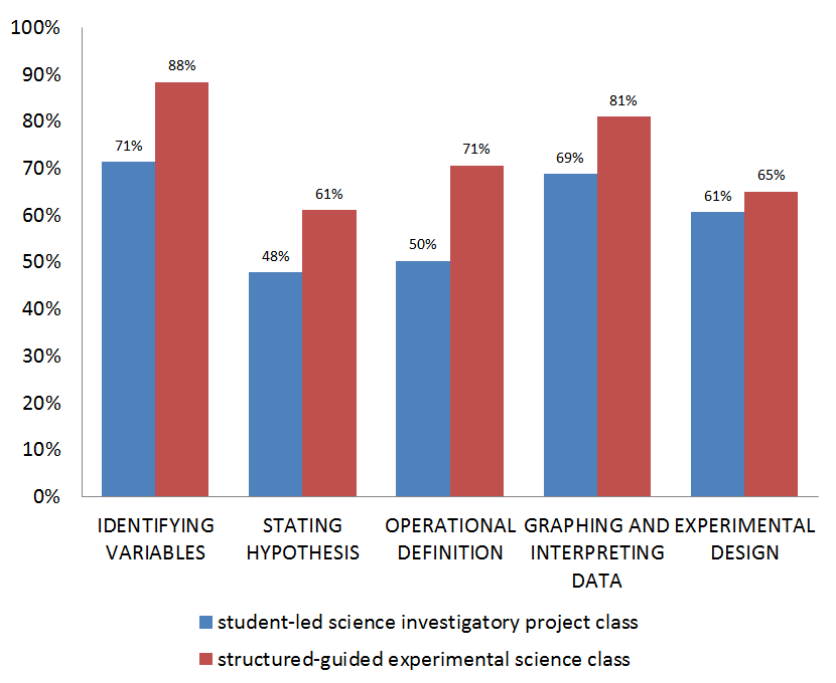

Fig. 1 Mean percentage of students' performance for each integrated science process skill

The results revealed that both classes have developed identifying and controlling the variables skill (rank 1) and graphing and interpreting graph skill (rank 2). However, students under the structured-guided experimental science class have developed these skills in advanced proficiency level while the student-led science investigation class has developed their identifying and controlling the variables skill and graphing and interpreting graph skill up to proficient level only.

Similarly, both classes least developed their stating hypothesis skill (rank 5). However, the structured-guided experimental science class has reached a proficient level while student-led science investigation class only reached the beginner level.

Statistical analysis through t-Test revealed that students of the structured-guided experimental science class have significantly higher scores in all skills except for experimental design skills in where both classes do not significantly differ in their scores.

\section{B. Overall Integrated Science Process Skills Proficiency Levels}

Overall analyses of students' proficiency level reveal that more students under the structured-guided experimental science class reached advanced proficiency. On the other hand, there are still students in the student-led science investigation class who are in the beginner level in their overall integrated science process skills. Statistical analysis of students' overall scores showed that students of the structured-guided experimental science class are significantly higher than that of the student-led science investigation class.

Science investigations utilize inquiry-based learning as its framework. As students conduct an investigation using the scientific method they gain an understanding of the nature of obtaining solutions to a problem in a systematic way.

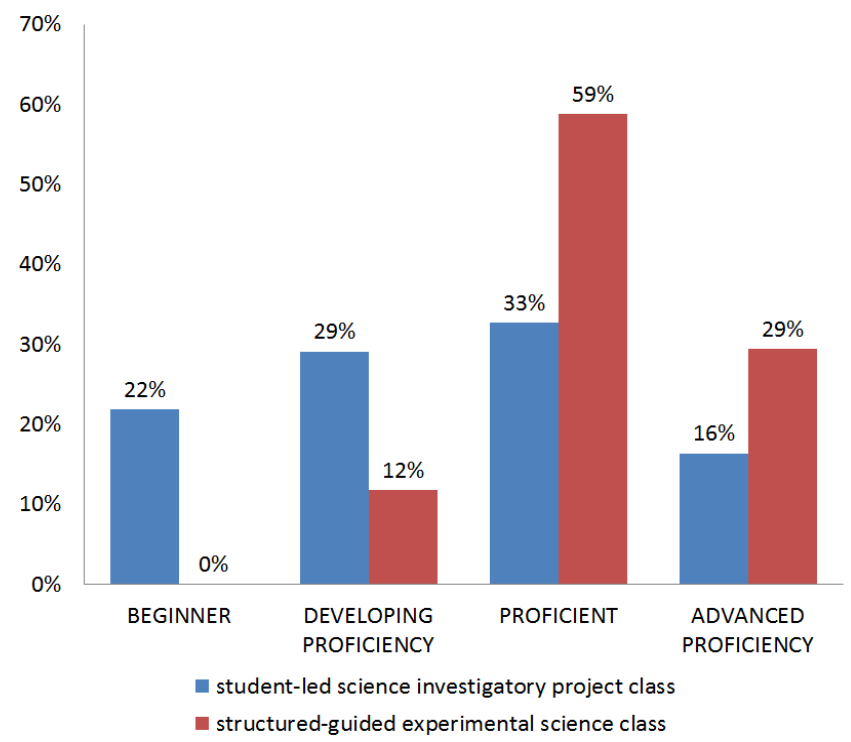

Fig. 2 Proficiency of students in the integrated science process skills test

Doing science investigations develop students' natural curiosity. They acquire the skills necessary to conduct inquiry and research and show independence in learning. They exercise initiative in applying thinking skills critically and creatively to pose and approach complex problems, identify variables, design appropriate experiments and make reasoned conclusions. This inquiry-based approach in learning allows the students understand science by operational defining variables in the context of their investigation. They are able to express ideas and information confidently and creatively in a variety of modes of communication such as graphs, written and oral presentations. This activity also allows them work effectively and willingly in collaboration with others.

By doing student-led investigations, the students are enabling them to manage their time in order to accomplish all tasks within the set deadlines. Collaborating with their partners to critically and positively analyze ideas and constant communication with the teacher, enable them to produce outstanding outputs. They are able to effectively and independently conduct literature reviews from different sources using different forms of technologies. Their knowledge and understanding are effectively transferred and communicated to solve the problem at hand. This activity enabled them to reflect and think of ideas to make a plan, present arguments in a logical sequence, identify problems and evaluate available solutions, and create strategies to solve the problem different perspectives.

However, results of this investigation reveal that structured-guided science investigations improved the integrated science process skills of students. Although, students want less structured science classes with less time devoted to lectures and note taking. They want the opportunity to do hands-on science activities that are relevant to their lives, the chance to discuss issues, and the 
time to explore issues in-depth. But still, the greatest influence on students' attitude and interest in science appears to be their science teachers. On the study of Gibson and Chase (2002), over $60 \%$ of the students interviewed spoke about their science teachers' influence [7]. Teachers' instructional methods have an impact on students' attitudes towards science. Their studies identify the importance of the learner having his or her own questions. Student generated questions play an important role in inquiry-based science classrooms. However, science teachers know how to use students' questions to guide instruction.

\section{Conclusion}

Science Investigation is a learning activity that is attuned with $21^{\text {st }}$ Century Education. This learning activity developed students' $21^{\text {st }}$ century skills as attested by their significantly improved approaches to learning skills. Students' proficiency in their integrated science process skills is significantly improved through a structured-guided investigation than a student-led investigation.

\section{Recommendations for Future Studies}

Further research is needed to compare the structuredguided science investigation program reported in this study to other inquiry-based programs. Second, additional studies are needed that follow students for longer periods of time after they take the structured-guided science investigation class. It would be enlightening to determine the impact of structured-guided science investigation program designed for middle school students have on students' streaming choices. And finally, while students showed a high level of proficiency in the integrated science process skills test, further studies should examine the correlation of among students' interest in science, their understanding of science and their science process skills.

\section{References}

[1] Pacific Policy Research Center, $21^{\text {st }}$ Century Skills for Students and Teachers, Honolulu: Kamehameha Schools, Research \& Evaluation Division, 2010.

[2] Center for $21^{\text {st }}$ Century Skills, "Six critical skills that form the foundation for $21^{\text {st }}$ century success," www.p21skills.org accessed May 15, 2014.

[3] Office of the Prime Minister's Science Advisory Committee, "Looking ahead: science education for the twenty-first century," A report from the Prime Minister's Chief Science Advisor. New Zealand, 2011.

[4] International Baccalaureate Organization, "Middle years programme sciences guide," United Kingdom, 2014.

[5] R. Jugar, "Teacher-coaches' perspectives on the validity and acceptability of commercial laboratory testing and analysis of high school science investigatory projects," Procedia-Social and Behavioral Sciences, pp. 2516-2521, 2013.

[6] M.M.M. Kazeni, "Development and validation of a test of integrated science process skills for the further education and training learners," unpublished, 2005.

[7] H. Gibson and C. Chase, "Longitudinal impact of an inquiry-based science program on middle school students' attitudes toward science," Wiley Periodicals, Inc., 2002. 